\title{
Effect of Sowing Date on Germination and Vigour of Soybean (Glycine max (L.) Merr) Seeds
}

\author{
M. M. Rahman ${ }^{1 *}$, M. M. Rahman ${ }^{2}$ and M. M. Hossain ${ }^{1}$ \\ ${ }^{1}$ Department of Agronomy, Bangladesh Agricultural University, Mymensingh \\ ${ }^{2}$ Willes Little Flower School and College, Dhaka, Bangladesh \\ *Corresponding author and Email: rahmanag63@yahoo.com
}

Received: 2 September 2012

Accepted: 18 May 2013

\begin{abstract}
An experiment was carried out at the Agronomy Field Laboratory of Bangladesh Agricultural University, Mymensingh during three consecutive seasons in 2004-2006 to find out the effect of sowing date on physiological quality of soybean seed. The experiments included six sowing dates viz. 4 Nov, 24 Nov, 14 Dec, 3 Jan, 23 Jan and 12 Feb and two cultivars namely G-2 and PB-1 in Rabi 2004-05; four sowing dates viz. 25 Jul, 14 Aug, 3 Sept and 23 Sept and three cultivars namely G-2, PB-1 and BS-5 in Kharif II 2005; four sowing dates viz. 26 Nov, 16 Dec, 5 Jan, and 25 Jan, and two cultivars viz. G-2 and PB-1 in Rabi 2005-06. The experiments were conducted in split-plot design with three replications. Results revealed that cultivar G-2 had higher germination and vigour than cultivar PB-1 or BS-5 in all the three seasons. November and December sowing produced seeds with higher germination and vigour for all the cultivars in Rabi season. On the other hand, September sowing produced seeds with high germination and vigour during Kharif II. The study indicated that soybean seeds with high germination and vigour could be obtained by sowing during November to December in Rabi season and August to September in Kharif-II season.
\end{abstract}

\section{Keywords: Soybean, seed, sowing date, germination, vigour}

\section{Introduction}

Soybean (Glycine $\max$ (L.) Merr) is the most important grain legume of the world and a new prospective crop for Bangladesh. Soybean seed contains $40-45 \%$ protein, $20-22 \%$ oil, $20-26 \%$ carbohydrate and a high amount of $\mathrm{Ca}, \mathrm{P}$ and vitamins (Rahman et al., 2011). Soybean oil is cholesterol free and is very popular as cooking oil over the world. Soybean protein contains essential amino acid in desired quantity. Hence, it is regarded as a well balanced protein food. Therefore, soybean has huge potential as healthy food. The grains of soybean can be used for making soyamilk, tofu and many other food products for human consumption and feed for animals.
The climatic and the edaphic conditions of Bangladesh are favorable for soybean production. Soybean can be cultivated throughout the year in Bangladesh. The yield of this crop is very low in this country compared to other soybean growing countries. Among the different reasons for low yield, the inadequate supply of quality seed is the most important one. The improper agronomic management, such as, sowing at wrong time may be a cause for this problem. It has been reported that the environment that helps production of good crop also helps producing good quality seed (Rahman et. al., 2005). The field environment at which the crop is grown and also seeds are harvested regulates the quality of seeds. Although 
information on the effect of sowing time on yield of soybean cultivars is available (Rahman et al., 2005), the report on the effect of sowing time on seed germination and vigour is scarce in Bangladesh. Therefore, the present research work was undertaken with a view to investigate the effect of sowing dates on germination, vigour and field performance of soybean seed.

\section{Materials and Methods}

\subsection{Experimental site, sowing and design}

Three field experiments were conducted at the Agronomy Field, Bangladesh Agricultural University, Mymensingh during Rabi 2004-05, Kharif II 2005 and Rabi 2005-06 seasons to study the effect of sowing dates on germination and vigour of soybean seed. The site is located at the $24^{0} 75^{\prime}$ North latitude and $90^{\circ} 50^{\prime}$ East longitudes and at an altitude of $18 \mathrm{~m}$. The soil of the site belongs to the Sonatala series of noncalcareous dark-grey floodplain soil under the Old Brahmaputra Floodplain Agro Ecological Zone, 'AEZ-9' (UNDP and FAO, 1988). The trial site was a medium high land having welldrained silty loam soil with $\mathrm{pH}$ 6.8. The soil contained $1.50 \%$ organic matter, $0.073 \%$ total nitrogen, $12.0 \mathrm{ppm}$ phosphorus, $9.5 \mathrm{ppm}$ sulphur, $0.47 \mathrm{ppm}$ zinc and $0.18 \%$ potassium. The soil test result revealed that the amount of $\mathrm{P}, \mathrm{K}, \mathrm{S}$ and $\mathrm{Zn}$ were relatively higher in Kharif-II season than those in Rabi season. The amount of total nitrogen was higher in Rabi season than in Kharif-II season.

The experiments comprised of six sowing dates viz. 4 November, 24 November, 14 December, 3 January, 23 January and 12 February and two soybean cultivars viz. Bangladesh Soybean-4 (G2) and Shohag (PB-1) in Rabi 2004-05 season, four sowing dates viz. 25 July, 14 August, 3 September and 23 September and three soybean cultivars viz. Bangladesh Soybean-4 (G-2), Shohag (PB-1) and BARI soybean -5 (BS-5) in kharif-II 2005 season; and four sowing dates viz. 26 Nov, 16 Dec, 5 Jan and 25 Jan and two cultivars viz., G-2 and PB-1 in Rabi 2005-06 season. The experiment was laid out in a split- plot design (sowing date as main plot and variety as sub plot) with three replications. The unit plot size was $4 \mathrm{~m} \times 3 \mathrm{~m}$. The preparatory tillage was done on 20 October 2004, 20 June 2005 and 15 November 2005 with a tractor drawn disc plough and subsequently prepared by harrowing and rolling with power tiller. Each unit plot was uniformly fertilized during final land preparation @ 23-69-60-16-1 kg ha ${ }^{-1} \quad \mathrm{~N}-\mathrm{P}_{2} \mathrm{O}_{5}-\mathrm{K}_{2} \mathrm{O}-\mathrm{S}-\mathrm{Zn}$ through urea, triple super phosphate, muriate of potash, gypsum and zinc sulphate, respectively (BARC, 2005).

Seeds were inoculated with Rhizobium inoculum @ $20 \mathrm{~g}$ of inoculums $\mathrm{kg}^{-1}$ of seed before sowing. . The seeds were sown continuously in a row to row distance of $30 \mathrm{~cm}$ by hand using @ $40 \mathrm{~kg}$ seeds $\mathrm{ha}^{-1}$ for cultivar G-2 and $70 \mathrm{~kg}$ seeds ha ${ }^{-1}$ for cultivar PB-1 and BS-5. Weeding was done manually at 20 and 40 days after sowing (DAS). At each weeding, extra seedlings were thinned out to maintain about $5 \mathrm{~cm}$ distances between plants in a row. Two irrigations were applied, one at 35 days after sowing (DAS) and the $2^{\text {nd }}$ one at 60 DAS for the 4 November 2004 sown crop (when soil moisture deficit reached to about $50 \%$ of field capacity). For rest of the sowing dates, only one irrigation was required which was applied at 31, 57, 37, 17 and 26 DAS for 24 November, 14 December 2004, 3 January, 23 January and 12 February 2005 sowings, respectively. In 2005-06 rabi season, one irrigation was required for each of the sowing dates that was applied at $45,25,52$, and 32 DAS for 26 Nov, 16 Dec, 5 Jan and 25 Jan sowings, respectively. No irrigation was required for Kharif-II 2005 crop. The crop plants were infested by cutworm (Agrotis ipsilon) and hairy caterpillar (Spilarctia obliqua) at early growth (vegetative) stages. The cutworm was controlled through hand picking and hairy caterpillar was successfully controlled by spraying Dimethion 40 EC @ $1.5 \mathrm{~L} \mathrm{ha}^{-1}$. No disease control measure was required for any of the seasons except for cultivar BS-5 sown on 24 November 2005, which was infested by leaf rust that was controlled by applying Cupravit @ $35 \mathrm{~kg} \mathrm{ha}^{-1}$ at 90 DAS. 
The crop was harvested from the central $3.6 \mathrm{~m}^{2}$ area $(3 \mathrm{~m} \times 1.2 \mathrm{~m})$ of each plot at full maturity (i.e. when $95 \%$ pods became brown). The cultivar G-2 was harvested on 20 February, 20 March, 2, 15, 23 April and 9 May 2005 for sowing on 4, 24 November, 14 December 2004, 3, 23 January and 12 February 2005, respectively. The cultivar PB-1 was harvested on 2 February, 2, 3, 10, 27 April and 9 May 2005 for sowing on 4, 24 November, 14 December 2004, 3, 23 January and 12 February 2005, respectively. In Kharif-II 2005 season, the cultivar G-2 was harvested on 27 October, 15, 27 November and 22 December 2005 for sowing on 25 July, 14 August, 3 and 23 September 2005, respectively. The cultivar BS-5 was harvested on 9 and 26 November, 4 and 20 December 2005 for 25 July, 14 August 3 and 23 September 2005, respectively. Cultivar PB-1 was harvested on 9 and 26 November, 4 and 21 December 2005 for the crop sown on 25 July, 14 August, 3 and 23 September 2005, respectively. For Rabi 2005-06 season, the crop was harvested on 28 March, 11 April, 16 April, and 29 April for cultivar G-2 and on 8 April, 13 April, 15 April and 25 April 2006 for cultivar PB-1 for sowing on 26 November, 16 December, 5 January and 25 January, respectively. After threshing, cleaning and drying with proper care, seeds were stored in air tight polythene bags at $8-9 \%$ moisture content. Data on germination and vigour of seed were recorded before and after storing. The field emergence of seed after storage was also recorded. The procedure of tests for germination, vigour and field emergence are stated below.

\subsection{Data Collection and Analysis}

\subsubsection{Seed germination}

Germination of seed was assessed at the beginning and also at 9 months after storing using modified paper folding method (ISTA, 1999). In this method, four replicates of 50 seeds were used. Fifty seeds randomly taken from the seed lot were placed on a double layer of moistened $23 \mathrm{~cm} \times 23 \mathrm{~cm}$ (Bashundhara kitchen towel) germination paper. After placing the seeds, another layer of moistened paper was placed on the top of the seeds. Then the paper was carefully folded into a roll and the four rolls were placed in a plastic bag to prevent moisture loss during germination. Eight bags were kept upright in a $25 \mathrm{~cm}$ high of plastic container and were placed into the germination chamber. After 8 days, seedlings were evaluated for germination capacity and categorized into normal seedlings, abnormal seedlings and dead seeds, respectively.

\subsubsection{Seed vigour}

Seed vigour index was estimated following the techniques recommended by ISTA (Hampton and TeKrony, 1995). In this method four replicates of 50 seeds were placed on each petridish lined with two layer of moistened germination paper. The number of seedling (2 $\mathrm{cm}$ radicle length), germinated at each day up to 8 days after setting the test, was recorded regularly. The vigour index was calculated as:

Number of seedling at first count Vigour Index = ------------------------------ + Days to first count Number of seedling at final count

Days to final count

\subsubsection{Field emergence}

At the end of storage period, field emergence (\%) of seed of each lot was evaluated by sowing 100 seeds in three replications in the well prepared field.

The collected data were statistically analyzed and differences among the treatment means were adjudged by Duncan's Multiple range Test with the help of a computer based statistical package program MSTAT-C.

\section{Results and Discussion}

\subsection{Germination}

Sowing date had significant influence on germination (\%) of soybean seed at the beginning and end of storage for both Rabi 2004/05 and 2005/06 seasons but not for Kharif- 
II 2005 season. Cultivars showed significant variation in germination $(\%)$ of soybean seed at the start and end of storage for all the three seasons, except at the end of storage for Rabi 2004/05 season. The germination of soybean seed at the start and end of storage differed due to interaction between sowing date and cultivar for all the seasons, except in Kharif II 2005 season for both at the beginning and end of storage and only for the beginning of storage for Rabi 2005/06 season (Table 1). In Rabi 2004-05, the seed from 4 November sown crop showed the highest germination of 98 and $93 \%$, respectively at the beginning and end of storage. The 12 February sown crop produced the seed with the lowest germination of $85 \%$ and $72 \%$ at the beginning and end of storage. In all the three seasons, cultivar G-2 gave the higher germination than cultivar BS-5 or PB-1 for both at the beginning and end of storage. In Kharif II 2005 season both BS-5 and PB-1 showed lower germination than cultivar G-2. It was noted that the cultivar BS-5 showed similar germination of seed to those obtained for cultivar PB-1 (Table 1). In case of sowing date $\times$ cultivar interaction, cultivar G-2 sown on 4 Nov, 2004, 23 September 2005 and 16 December 2005 gave the highest germination for both before and after storage. Cultivar BS-5 in 2004/05 gave the highest germination for sowing on 3 January, for kharif 2004/05 season and PB-1 for sowing on 5 January 2006. The general trend was that November sowing was better for cultivar G-2, though early January sowing gave the highest germination for BS-5 and PB-1 cultivars.

\subsection{Vigour index}

Vigour index was influenced significantly by sowing date, cultivar and their interaction in Rabi 2004-05, Kharif-II 2005 and Rabi 2005/06 seasons for both at beginning and end of storage, except that at beginning of storage for sowing in Rabi 2005/06 season (Table 2). Irrespective of variety, the highest vigour index was found for 4 Nov, 25 July and 16 December for Rabi 200405, Kharif II 2005 and Rabi 2005/06 seasons, respectively. In both the rabi seasons the vigour index decreased with delay in sowing but that increased with delay in sowing in Kharif II 2005 season. In all the three seasons, the vigour index was higher in cultivar G-2 than that for BS-5 or PB-1. For both the varieties in Rabi 2004/05 and 2005/06 seasons, the vigour index decreased with delay in sowing but delayed sowing showed higher vigour index for all the three cultivars in Kharif II 2005 season. For example, the seed from the 23 September sowing resulted in higher vigour index than the other three sowing dates both at the beginning (43.19) and end (36.19) of storage. The seed from 25 July sown crop gave the lowest vigour index of 39.35 and 30.90, respectively at the beginning and end of the storage, which were statistically similar with those values obtained for seed from 14 August and 3 September sowings. Cultivar G-2 acquired the highest vigour index of 46.73 and 39.94, respectively at the beginning and end of the storage, while the lowest vigour index of 35.01 and 28.32, respectively was found with cultivar BS-5. At the beginning of storage, cultivar PB-1 showed higher vigour index (39.63) than cultivar BS-5 but at the end of storage vigour index of cultivar PB-1 and cultivar BS-5 became identical (Table 2). In Rabi 2004-05 season, cultivar G-2 for 4 November sowing gave the highest vigour index for both at the beginning (41) and end (37) of the storage, while cultivar BS-5 sown on 12 February gave the lowest vigour index (20) at the beginning of storage (Table 2). However, at the end of storage, cultivar BS-5 gave the lowest (13\%) vigour index when the crop sown on 23 January, which was at par by same cultivar with 12 February sowing.

In Kharif-II 2005 season, the interaction of sowing date and cultivar showed that both at the beginning and end of storage, cultivar G-2 sown on 23 September gave the highest vigour index of 48.98 and 48.42 , respectively. The seed of cultivar G-2 from 3 September, 14 August and cultivar PB-1 from 23 September exhibited similar vigour index to that obtained from cultivar G-2 from 23 September sowing. The lowest vigour index both at the beginning and end of the storage was observed for seed of cultivar BS-5 from 3 September sowing (Table 2). 
Table 1. Effect of sowing date and cultivar on germination (\%) of soybean seed in Rabi 2004-05, Kharif-II 2005 and Rabi $2005-06$ seasons

\begin{tabular}{|c|c|c|c|c|c|c|c|c|}
\hline \multicolumn{3}{|c|}{ Rabi 2004-05 } & \multicolumn{3}{|c|}{ Kharif-II 2005} & \multicolumn{3}{|c|}{ Rabi 2005-06 } \\
\hline & \multicolumn{2}{|c|}{ Germination (\%) } & & \multicolumn{2}{|c|}{ Germination (\%) } & & \multicolumn{2}{|c|}{ Germination (\%) } \\
\hline Sowing date & $\mathrm{BS}$ & AS & Sowing date & $\mathrm{BS}$ & $\mathrm{AS}$ & Sowing date & $\mathrm{BS}$ & $\mathrm{AS}$ \\
\hline $4 \mathrm{Nov}$ & $97.83 \mathrm{a}$ & $92.67 \mathrm{a}$ & $25 \mathrm{Jul}$ & 93.78 & 90.67 & $26 \mathrm{Nov}$ & $84.17 b$ & $76.00 \mathrm{~b}$ \\
\hline 24 Nov & $91.83 b$ & $78.33 \mathrm{c}$ & 14 Aug & 95.56 & 90.44 & $16 \mathrm{Dec}$ & $86.72 \mathrm{ab}$ & $81.50 \mathrm{a}$ \\
\hline $14 \mathrm{Dec}$ & $88.83 \mathrm{bc}$ & $75.67 \mathrm{c}$ & $3 \mathrm{Sep}$ & 95.89 & 92.56 & 5 Jan & $89.72 \mathrm{a}$ & $80.06 a$ \\
\hline 3 Jan & $89.17 b c$ & $83.33 b$ & 23 Sep & 96.33 & 92.33 & $25 \mathrm{Jan}$ & $84.67 b$ & $75.33 b$ \\
\hline 23 Jan & $88.17 \mathrm{~cd}$ & $77.67 \mathrm{c}$ & $\mathrm{CV}(\%)$ & 2.36 & 6.17 & $\mathrm{CV}(\%)$ & 5.00 & 2.92 \\
\hline $12 \mathrm{Feb}$ & $85.00 \mathrm{~d}$ & $72.33 \mathrm{~d}$ & $\mathrm{SE}( \pm)$ & 1.126 & 7.083 & $\mathrm{SE}( \pm)$ & 6.209 & 1.739 \\
\hline $\mathrm{CV}(\%)$ & 2.89 & 2.82 & & & & & & \\
\hline $\mathrm{SE}( \pm)$ & 2.262 & 1.697 & & & & & & \\
\hline Cultivar & & & Cultivar & & & Cultivar & & \\
\hline G-2 & $92.66 \mathrm{a}$ & 79.89 & G-2 & $98.17 \mathrm{a}$ & $95.67 \mathrm{a}$ & G-2 & $89.58 \mathrm{a}$ & $81.67 \mathrm{a}$ \\
\hline BS-5 & $87.61 \mathrm{~b}$ & 80.11 & BS-5 & $93.50 \mathrm{~b}$ & $88.08 \mathrm{~b}$ & PB-1 & $83.06 \mathrm{~b}$ & $74.78 b$ \\
\hline $\mathrm{CV}(\%)$ & 4.01 & 3.78 & PB-1 & $94.50 \mathrm{~b}$ & $90.75 b$ & $\mathrm{CV}(\%)$ & 4.17 & 4.56 \\
\hline \multirow[t]{2}{*}{$\mathrm{SE}( \pm)$} & 1.452 & 1.016 & $\mathrm{CV}(\%)$ & 2.81 & 6.08 & $\mathrm{SE}( \pm)$ & 2.159 & 2.120 \\
\hline & & & $\mathrm{SE}( \pm)$ & 1.197 & 5.158 & & & \\
\hline \multicolumn{3}{|c|}{ Sowing date $\mathrm{x}$ variety } & \multicolumn{3}{|c|}{ Sowing date $\mathrm{x}$ variety } & \multicolumn{3}{|c|}{ Sowing date $\mathrm{x}$ variety } \\
\hline 4 Nov x G-2 & $97.67 \mathrm{a}$ & $94.67 \mathrm{a}$ & 25 Jul x G-2 & 96.00 & 91.00 & 26 Nov x G-2 & 86.67 & $78.67 b$ \\
\hline 24 Nov x G-2 & $92.67 \mathrm{abc}$ & $80.67 \mathrm{~cd}$ & 14 Aug x G-2 & 98.00 & 94.33 & 16 Dec x G-2 & 90.78 & $86.89 \mathrm{a}$ \\
\hline 14 Dec x G-2 & $96.00 \mathrm{ab}$ & $77.33 \mathrm{de}$ & 3 Sep x G-2 & 98.67 & 98.33 & 5 Jan x G-2 & 93.67 & $83.78 \mathrm{a}$ \\
\hline 3 Jan x G-2 & $88.00 \mathrm{~cd}$ & $80.67 \mathrm{~cd}$ & 23 Sep x G-2 & 100.00 & 99.00 & 25 Jan x G-2 & 87.22 & $77.33 b$ \\
\hline 23 Jan x G-2 & $91.33 \mathrm{abc}$ & $71.33 \mathrm{fg}$ & $25 \mathrm{Jul} \times \mathrm{BS}-5$ & 90.00 & 87.00 & 26 Nov x PB-1 & 81.67 & $73.33 \mathrm{c}$ \\
\hline 12 Feb x G-2 & $91.00 \mathrm{abc}$ & 74.67efg & 14 Aug x BS-5 & 93.67 & 85.00 & 16 Dec x PB-1 & 82.67 & $76.11 \mathrm{bc}$ \\
\hline 4 Nov x BS-5 & $98.00 \mathrm{a}$ & $90.67 \mathrm{ab}$ & 3 Sep x BS-5 & 95.00 & 89.33 & 5 Jan x PB-1 & 85.78 & $76.33 b c$ \\
\hline 24 Nov x BS-5 & $91.67 \mathrm{abc}$ & 76.00def & 23 Sep x BS-5 & 95.33 & 91.00 & 25 Jan x PB-1 & 82.11 & $73.33 c$ \\
\hline 14 Dec x BS-5 & $81.67 \mathrm{de}$ & 74.00efg & 25 Jul x PB-1 & 95.00 & 94.00 & CV $(\%)$ & 4.17 & 4.56 \\
\hline 3 Jan x BS-5 & $90.33 b c$ & $86.00 \mathrm{bc}$ & 14 Aug x PB-1 & 95.00 & 92.00 & $\mathrm{SE}( \pm)$ & 8.638 & 8.482 \\
\hline 23 Jan $x$ BS-5 & $85.00 \mathrm{cde}$ & $84.00 \mathrm{c}$ & 3 Sep x PB-1 & 94.00 & 90.00 & & & \\
\hline 12 Feb x BS-5 & $79.00 \mathrm{e}$ & $70.00 \mathrm{~g}$ & 23 Sep x PB-1 & 93.67 & 87.00 & & & \\
\hline $\mathrm{CV}(\%)$ & 4.01 & 3.78 & $\mathrm{CV}(\%)$ & 2.81 & 6.08 & & & \\
\hline $\mathrm{SE}( \pm)$ & 8.721 & 6.097 & $\mathrm{SE}( \pm)$ & 4.787 & 20.632 & & & \\
\hline
\end{tabular}

Figures having similar letter (s) do not differ significantly at $5 \%$ level as per DMRT 
Table 2. Effect of sowing date and cultivar on vigour index of soybean seed in Rabi 2004-05, Kharif-II 2005 and Rabi $2005-06$ seasons

\begin{tabular}{|c|c|c|c|c|c|c|c|c|}
\hline \multicolumn{3}{|c|}{ Rabi 2004-05 } & \multicolumn{3}{|c|}{ Kharif-II 2005} & \multicolumn{3}{|c|}{ Rabi 2005-06 } \\
\hline & \multicolumn{2}{|c|}{ Vigour index } & \multicolumn{3}{|c|}{ Vigour index } & \multicolumn{3}{|c|}{ Vigour index } \\
\hline Sowing date & $\mathrm{BS}$ & AS & Sowing date & $\mathrm{BS}$ & AS & Sowing date & $\mathrm{BS}$ & AS \\
\hline $4 \mathrm{Nov}$ & $37.81 \mathrm{a}$ & $27.44 a$ & $25 \mathrm{Jul}$ & $39.35 b$ & $30.90 \mathrm{~b}$ & $26 \mathrm{Nov}$ & 36.51 & $20.46 b$ \\
\hline $24 \mathrm{Nov}$ & $29.78 b$ & $19.38 \mathrm{c}$ & 14 Aug & $39.74 b$ & $30.69 b$ & $16 \mathrm{Dec}$ & 36.05 & $24.14 \mathrm{a}$ \\
\hline $14 \mathrm{Dec}$ & $26.06 b c$ & $23.37 b$ & 3 Sep & $39.55 b$ & $32.33 b$ & 5 Jan & 36.03 & $19.76 \mathrm{c}$ \\
\hline $3 \mathrm{Jan}$ & $26.88 b c$ & $23.39 b$ & 23 Sep & $43.19 \mathrm{a}$ & $36.19 \mathrm{a}$ & $25 \mathrm{Jan}$ & 35.37 & $17.82 \mathrm{~d}$ \\
\hline $23 \mathrm{Jan}$ & $27.74 b c$ & $16.79 \mathrm{~d}$ & $\mathrm{CV}(\%)$ & 6.12 & 6.64 & $\mathrm{CV}(\%)$ & 5.04 & 4.12 \\
\hline 12 Feb & $25.62 \mathrm{c}$ & $15.56 \mathrm{~d}$ & $\mathrm{SE}( \pm)$ & 1.362 & 1.037 & $\mathrm{SE}( \pm)$ & 1.097 & 0.239 \\
\hline $\mathrm{CV}(\%)$ & 9.33 & 9.46 & & & & & & \\
\hline $\mathrm{SE}( \pm)$ & 2.437 & 1.314 & & & & & & \\
\hline Cultivar & & & Cultivar & & & Cultivar & & \\
\hline $\mathrm{G}-2$ & $30.83 a$ & $24.72 \mathrm{a}$ & $\mathrm{G}-2$ & $46.73 a$ & $39.94 a$ & G-2 & $39.40 \mathrm{a}$ & $24.64 a$ \\
\hline BS-5 & $27.13 b$ & $17.27 \mathrm{~b}$ & BS-5 & $35.01 \mathrm{c}$ & $28.32 b$ & PB-1 & $32.58 b$ & $16.46 b$ \\
\hline $\mathrm{CV}(\%)$ & 9.31 & 6.93 & PB-1 & $39.63 b$ & $29.33 b$ & $\mathrm{CV}(\%)$ & 6.78 & 9.56 \\
\hline \multirow[t]{2}{*}{$\mathrm{SE}( \pm)$} & 0.809 & 0.235 & $\mathrm{CV}(\%)$ & 5.43 & 6.12 & $\mathrm{SE}( \pm)$ & 0.992 & 0.643 \\
\hline & & & $\mathrm{SE}( \pm)$ & 0.804 & 0.661 & & & \\
\hline \multicolumn{3}{|c|}{ Sowing date $\mathrm{x}$ variety } & \multicolumn{3}{|c|}{ Sowing date $\mathrm{x}$ variety } & \multicolumn{3}{|c|}{ Sowing date $\mathrm{x}$ variety } \\
\hline 4 Nov x G-2 & $41.33 \mathrm{a}$ & $37.10 \mathrm{a}$ & 25 Jul x G-2 & $43.94 b$ & $33.39 \mathrm{~cd}$ & 26 Nov x G-2 & $39.81 \mathrm{ab}$ & $23.79 b$ \\
\hline 24 Nov x G-2 & $34.95 b$ & $23.88 b$ & 14 Aug x G-2 & $46.76 \mathrm{ab}$ & $35.75 \mathrm{c}$ & 16 Dec x G-2 & $41.79 a$ & $27.66 \mathrm{a}$ \\
\hline 14 Dec x G-2 & $27.27 \mathrm{~cd}$ & $21.34 \mathrm{c}$ & 3 Sep x G-2 & $47.22 \mathrm{ab}$ & $42.19 b$ & 5 Jan x G-2 & $39.32 b$ & $23.96 b$ \\
\hline 3 Jan x G-2 & $29.15 \mathrm{c}$ & $21.32 \mathrm{c}$ & 23 Sep x G-2 & $48.98 \mathrm{a}$ & $48.42 \mathrm{a}$ & 25 Jan $x$ G-2 & $36.67 \mathrm{c}$ & $23.14 b$ \\
\hline 23 Jan x G-2 & $27.49 \mathrm{~cd}$ & $21.24 \mathrm{c}$ & $25 \mathrm{Jul} \times \mathrm{BS}-5$ & $37.11 \mathrm{c}$ & $30.15 \mathrm{def}$ & 26 Nov x PB-1 & $33.21 \mathrm{~d}$ & $17.12 \mathrm{~d}$ \\
\hline 12 Feb x G-2 & $23.47 \mathrm{de}$ & $15.29 \mathrm{def}$ & 14 Aug x BS-5 & $35.06 \mathrm{c}$ & $27.32 \mathrm{f}$ & 16 Dec x PB-1 & $30.31 \mathrm{e}$ & $20.62 \mathrm{c}$ \\
\hline 4 Nov x BS-5 & $27.77 \mathrm{~cd}$ & $24.74 b$ & 3 Sep x BS-5 & $33.99 \mathrm{c}$ & $26.88 \mathrm{f}$ & 5 Jan x PB-1 & $32.74 d$ & $15.59 \mathrm{~d}$ \\
\hline 24 Nov $x$ BS-5 & $22.97 \mathrm{de}$ & $17.13 d$ & 23 Sep x BS-5 & $33.89 \mathrm{c}$ & $28.92 \mathrm{ef}$ & 25 Jan x PB-1 & $34.07 \mathrm{~d}$ & $12.50 \mathrm{e}$ \\
\hline 14 Dec x BS-5 & $35.72 b$ & $15.98 \mathrm{de}$ & 25 Jul x PB-1 & $36.99 \mathrm{c}$ & $29.17 \mathrm{ef}$ & CV $(\%)$ & 6.78 & 9.56 \\
\hline 3 Jan x BS-5 & 38.38ab & $14.60 \mathrm{ef}$ & 14 Aug x PB-1 & $37.40 \mathrm{c}$ & 28.99ef & $\mathrm{SE}( \pm)$ & 3.969 & 2.573 \\
\hline 23 Jan $x$ BS-5 & $34.38 \mathrm{~b}$ & $12.90 \mathrm{f}$ & 3 Sep x PB-1 & $37.44 \mathrm{c}$ & $27.92 \mathrm{ef}$ & & & \\
\hline 12 Feb x BS-5 & $19.81 \mathrm{e}$ & $13.44 \mathrm{f}$ & 23 Sep x PB-1 & $46.69 \mathrm{ab}$ & $31.22 \mathrm{de}$ & & & \\
\hline $\mathrm{CV}(\%)$ & 9.6 & 6.51 & CV $(\%)$ & 5.43 & 6.12 & & & \\
\hline $\mathrm{SE}( \pm)$ & 5.612 & 1.120 & $\mathrm{SE}( \pm)$ & 3.217 & 2.642 & & & \\
\hline
\end{tabular}

Figures having similar letter (s) do not differ significantly at $5 \%$ level as per DMRT 
Table 3. Effect of sowing date and cultivar on after storage field emergence of soybean seed in Rabi 2004-05, Kharif-II 2005 and Rabi 2005-06 seasons

\begin{tabular}{|c|c|c|c|c|c|}
\hline \multicolumn{2}{|c|}{ Rabi 2004-05 } & \multicolumn{2}{|c|}{ Kharif-II 2005} & \multicolumn{2}{|c|}{ Rabi 2005-06 } \\
\hline & Field emergence $(\%)$ & & Field emergence $(\%)$ & & Field emergence (\%) \\
\hline Sowing date & & Sowing date & & Sowing date & \\
\hline $4 \mathrm{Nov}$ & $72.00 \mathrm{a}$ & $25 \mathrm{Jul}$ & $63.22 \mathrm{c}$ & $26 \mathrm{Nov}$ & $54.33 \mathrm{a}$ \\
\hline 24 Nov & $61.50 \mathrm{c}$ & 14 Aug & $63.11 \mathrm{c}$ & $16 \mathrm{Dec}$ & $49.33 b$ \\
\hline $14 \mathrm{Dec}$ & $68.00 \mathrm{~b}$ & 3 Sep & $70.67 b$ & $5 \mathrm{Jan}$ & $49.17 b$ \\
\hline 3 Jan & $69.50 \mathrm{~b}$ & $23 \mathrm{Sep}$ & $74.33 \mathrm{a}$ & $25 \mathrm{Jan}$ & $48.61 \mathrm{~b}$ \\
\hline 23 Jan & $60.00 \mathrm{c}$ & $\mathrm{CV}(\%)$ & 6.52 & $\mathrm{CV}(\%)$ & 6.72 \\
\hline $12 \mathrm{Feb}$ & $58.00 \mathrm{~d}$ & $\mathrm{SE}( \pm)$ & 4.347 & $\mathrm{SE}( \pm)$ & 3.818 \\
\hline $\mathrm{CV}(\%)$ & 1.91 & & & & \\
\hline $\mathrm{SE}( \pm)$ & 0.511 & & & & \\
\hline Cultivar & & Cultivar & & Cultivar & \\
\hline $\mathrm{G}-2$ & $69.67 \mathrm{a}$ & G-2 & $77.75 \mathrm{a}$ & $\mathrm{G}-2$ & $56.06 a$ \\
\hline BS-5 & $60.00 \mathrm{~b}$ & BS-5 & $61.67 \mathrm{~b}$ & PB-1 & $44.67 \mathrm{~b}$ \\
\hline $\mathrm{CV}(\%)$ & 8.70 & PB-1 & $64.08 \mathrm{~b}$ & $\mathrm{CV}(\%)$ & 8.05 \\
\hline $\mathrm{SE}( \pm)$ & 3.535 & $\mathrm{CV}(\%)$ & 4.33 & $\mathrm{SE}( \pm)$ & 2.739 \\
\hline & & $\mathrm{SE}( \pm)$ & 1.438 & & \\
\hline Sowing date $\mathrm{x} v$ & & Sowing date $\mathrm{x}$ va & & Sowing date $\mathrm{x}$ & \\
\hline Rabi 2004-05 & & Kharif-II 2005 & & Rabi 2005-06 & \\
\hline 4 Nov x G-2 & 79.00 & 25 Jul x G-2 & $69.33 c$ & 26 Nov x G-2 & $57.22 \mathrm{a}$ \\
\hline 24 Nov x G-2 & 72.00 & 14 Aug x G-2 & $76.67 b$ & 16 Dec x G-2 & $56.33 \mathrm{a}$ \\
\hline 14 Dec x G-2 & 70.00 & 3 Sep x G-2 & $81.33 \mathrm{ab}$ & 5 Jan x G-2 & $53.89 \mathrm{ab}$ \\
\hline 3 Jan x G-2 & 71.00 & 23 Sep x G-2 & $83.67 \mathrm{a}$ & 25 Jan x G-2 & $56.78 \mathrm{a}$ \\
\hline 23 Jan $x$ G-2 & 64.00 & $25 \mathrm{Jul}$ x BS-5 & $61.33 \mathrm{e}$ & 26 Nov x PB-1 & $51.44 \mathrm{~b}$ \\
\hline 12 Feb x G-2 & 62.00 & 14 Aug x BS-5 & $52.00 \mathrm{f}$ & 16 Dec x PB-1 & $42.33 c$ \\
\hline 4 Nov x BS-5 & 65.00 & 3 Sep x BS-5 & 63.00de & 5 Jan x PB-1 & $44.44 \mathrm{c}$ \\
\hline 24 Nov x BS-5 & 51.00 & 23 Sep x BS-5 & $70.33 c$ & 25 Jan x PB-1 & $40.44 c$ \\
\hline 14 Dec x BS-5 & 66.00 & 25 Jul x PB-1 & $59.00 \mathrm{e}$ & CV $(\%)$ & 8.05 \\
\hline 3 Jan x BS-5 & 68.00 & 14 Aug x PB-1 & $60.67 \mathrm{e}$ & $\mathrm{SE}( \pm)$ & 10.956 \\
\hline 23 Jan x BS-5 & 56.00 & 3 Sep x PB-1 & $67.67 \mathrm{~cd}$ & & \\
\hline 12 Feb x BS-5 & 54.00 & 23 Sep x PB-1 & $69.00 \mathrm{c}$ & & \\
\hline CV $(\%)$ & 8.70 & $\mathrm{CV}(\%)$ & 4.33 & & \\
\hline $\mathrm{SE}( \pm)$ & 21.210 & $\mathrm{SE}( \pm)$ & 5.571 & & \\
\hline
\end{tabular}

Figures having similar letter (s) do not differ significantly at 5\% level as per DMRT 


\subsection{Field emergence}

Sowing date, cultivar and sowing date by cultivar interaction exhibited significant effects on field emergence of stored seed for Rabi 20042005, Kharif-II 2005 and Rabi 2005/06 seasons (Table 3). In both the rabi seasons, the field emergence decreased with delay in sowing date but the delay in sowing increased the field emergence in Kharif-II 2005 season. Cultivar G2 showed the highest rate of field emergence in all the three seasons. The field emergence of seed was the highest (72\%) for 4 November sown crop of Rabi 2004-05 season but the lowest (58\%) for 12 February sowing. In Kharif-II 2005 season, field emergence attained the highest (74\%) for seed from 23 September sowing and the lowest (63\%) from 14 August sowing that was at par with 25 July. For Rabi 2005/06 season, the highest field emergence of $74 \%$ was found with 23 September sowing (Table 3). Cultivar G-2 sown on 4 Nov and 26 Nov showed the highest field emergence of $79 \%$ and 57\% in Rabi 2004/05 and 2005/06 seasons. The cultivar BS-5 sown on 3 Jan and cultivar PB-1 sown on 26 November gave their highest emergence in field in Rabi 2004/05 and 2005/06 seasons. In Kharif-II 2005 season, cultivar G-2 sown on 23 September had the highest field emergence $(84 \%)$ while cultivar PB-1 sown on 25 July obtained the lowest (53\%) (Table 3).

The relationship of field emergence with seed germination and vigour index was measured in term of correlation coefficient. The result showed that there was a strong positive correlation of field emergence with either laboratory germination or vigour index at the beginning of storage and end of storage for all the three seasons except with the germination at the beginning of storage in Rabi 2004/05 season.

The significant positive relationship of field emergence with the laboratory germination and vigour index values of the seed both at the beginning and end of storage (Table 4) indicated that germination and vigour index could be considered as the potential indicators for actual field establishment of the seed lot. The result of the present study also revealed that in most of the cases the seed lot, which had the highest germination also had the maximum vigour index. For example, seeds of cultivar G-2 from sowing on 4 November 2004, 23 September 2005 and 16 December 2005, respectively in Rabi 2004-05, Kharif-II 2005 and Rabi 2005-06 seasons gave its highest germination and vigour index both at the beginning and end of storage period of seed. Similar result was also found for the other two cultivars. Thus, the present study confirmed that the crop environment that gives higher seed yield also produces seed lot with high germination and vigour index (Rahman et al., 2004). Variation in seed germination and vigour due to variation in sowing date has also been reported by previous workers (Adam et al., 1989; Rahman et al., 2005; TeKrony et al., 1997). The variation in seed germination and vigour comes from the environmental conditions that the crop experiences during the seed development and maturation (Dornbos, 1995). Adam et al. (1989) reported that early sowing was associated with high yield and quality than late sowing in Ohio, USA. The higher seed quality of high yield crops in sowing date trial may be supported by Dornbos (1995) who found a high correlation of germination with seed size having higher germination with the larger seeds. Thus, the higher individual seed weight might have been related to higher germination of the crop (Hampton et al., 2005). The germination and vigour index of seed decreased with delay in sowing in both the rabi seasons.

\section{Conclusions}

Germination and vigour of soybean seed is influenced by the cultivar and their time of sowing. Among the three varieties, cultivar G-2 showed higher germination and vigour than cultivar PB-1 or BS-5 during both rabi and kharif seasons. November and December sowing produced seeds with higher germination and vigour for all the cultivars in Rabi season. On the other hand, September sowing produced seeds with high germination and vigour during Kharif 
II. The study concludes that soybean seeds having high germination and vigour could be obtained by sowing of seed during November to December and August to September in Rabi and Kharif-II seasons, respectively.

\section{References}

Adam, N. M., McDonald, Jr. M. B. and Henerlong, P. R. 1989. The influence of seed position, planting and harvesting dates on soybean seed quality. Seed Science and Technology, 17: 143-152.

BARC (Bangladesh Agricultural Research Council). 2005. Fertilizer Recommendation Guide - 2005. Bangladesh Agricultural Research Council, Farmgate, New Air Port Road, Dhaka. p. 96.

Dornbos, D. L. Jr. 1995. Production environment and seed quality. In: Seed Quality: Basic Mechanisms and Agricultural Implication (ed. A. S. Basra), Food Product Press, New York. pp. 119-152.

Hampton, J. G., Rahman, M. M., Mwakangwale, M. G. and Hill, M. J. 2005. Does seed weight explain seed vigour differences in seeds from different pod positions on the plant? Seed Science and Technology. 33 : 499-503.
Hampton, J. G. and TeKrony, D. M. 1995. Handbook of Vigour Test Methods $\left(3^{\text {rd }}\right.$ edn.), International Seed Testing Association, Zurich, Switzerland.

ISTA. 1999. International rules for seed testing, 1999. Supplement to Seed Science and Technology, 27: 27-32.

Rahman, M. M., Hossain, M. M., Anwar, M. P. and Juraimi, A. S. 2011. Plant density influence on yield and nutritional quality of soybean seed. Asian Journal of Plant Sciences. 10(2) : 125-132.

Rahman, M. M., Hampton, J. G. and Hill, M. J. 2005. Soybean seed yield as affected by time of sowing in a cool temperature environment. Seed Science and Technology, 7: 1-15.

TeKrony, D. M., Egli, D. B., Ellis, R. H., Black, M., Murdoch, A.J. and Hong, T.D. 1997. Accumulation of seed vigour during development and maturation. Plant Science and Biotechnology in Agriculture, 30: 369-384.

UNDP and FAO. 1988. Land Resources Appraisal of Bangladesh for Agriculturist Development. Report No. 2. Agroecological Regions of Bangladesh. United Nations Development Programme on Food and Agriculture Organization, pp. 212-221. 